\title{
QUANTITATIVE EVALUATION OF ECOTOURISTS' VALUE COGNITION BASED ON CHOICE EXPERIMENT: THE CASE OF ZHEJIANG, CHINA
}

\author{
SU, Y. X. - YAN, L. J. \\ College of Life Sciences, Zhejiang University, China. \\ 866 Yuhangtang Road, Hangzhou, Zhejiang Province, 310058, P. R. China \\ (phone: +86-571-88206472; fax: +86-571-88981358) \\ *Corresponding author \\ e-mail: tulipblue16@zju.edu.cn \\ (phone: +86-571-88206605; fax: +86-571-88206207) \\ (Received $24^{\text {th }}$ Oct 2016; accepted $9^{\text {th }}$ Nov 2016)
}

\begin{abstract}
Although an important part of ecotourism, there are not many researches on environmental ethics in ecotourism, especially in a quantitative way. This paper took tourists' value cognition as the research object and creatively introduced the choice experiment (CE) approach in eco-economics aiming at work out the suitable experimental model for environmental ethics based quantitative researches. Ecotourists of three ecological counties in Zhejiang, China were investigated. Their cognition of ecological values was converted into virtual willingness of payment for four aspects in ecotourism improvement (ecological treatment measures, environmental education, tourist amount control and special rural features) and they were found to prefer an enhanced state of the four aspects. It was also showed in the survey that ecotourists' value cognition was influenced by their ecotourism experiences, gender, education background and income level. Based on the findings, policy suggestions were presented in four perspectives: the importance of ecological treatment measures, compensation for deficiency in environmental education, control of market size and flexible use of rural elements. With the help of CE, the results of environmental ethics research would be a more scientific basis for the value cognition research and summary.
\end{abstract}

Keywords: ecotourism; environmental ethics; CVM; CE; questionnaire survey

\section{Introduction}

At the end of the $20^{\text {th }}$ century, with the booming of popular tourism, its negative influences on resources, cultures and environment became more serious. To reach a sustainable development where tourism could be fully developed without unnecessary harm or with minimum harm to the above factors, ecotourism was put forward after a theoretical and practical consideration of alternative tourism. The term "ecotourism" was first used in a published article by Mexican expert Ceballos-Lascurain (1991), who was also a special advisor to the International Union for Conservation of Nature (IUCN), and later the term was officially adopted on the International Conference on Environment held in Mexico 1986. In 1988, Ceballos-Lascurain defined ecotourism as "a form of conventional tourism in which tourists are exposed to a relatively primitive natural area so that they can appreciate both ancient and modern cultures while studying 
and enjoying the beautiful sceneries and wildlife." (Ceballos-Lascurain, 1991; Fennell, 2000).

As the development of ecotourism, the study of it is conducted in all aspects in different kinds of territories by researchers around the world (Chakrabarty, 2011; Blersch and Kangas, 2013; Broadbent et al., 2012; Salum, 2009; Li et al., 2012). Most researches are focused on regional development and prospects of ecotourism from the perspectives of sociology or economics (Russell, 2007; Torres-Sovero et al., 2012; Reimer and Walter, 2012; Koens et al., 2009; Muehlenbein et al., 2010; Bandara, 2009; Wurzinger and Johansson, 2006; Snyman, 2012; Winkle, 2011). These researches may start for the benefit of different groups of people, such as managers, operators, tourists, or even upper decision makers, but they all reflect the interactive relationship between "human" and "nature" in ecotourism as well as the influence of human activities on nature. The focus of ecotourism researches should not be separated with the study of "humans" and that is why the concept and thinking method of "environmental ethics" needs to be introduced.

Since the middle of the twentieth century, environmental problems became more and more serious and people's environmental awareness was awakened. The term "environmental ethics" appeared more often in people's life. Environmental ethics is a comprehensive subject related to ethics and environmental sciences. It aims at solutions to the contradiction between human and environment as well as an effective coordination of them. Among various versions of the definition of ecotourism, "environmental education" and "ethics" are most commonly mentioned (Fennell, 2011). It is safe to say that environmental ethics per se is an indispensable part of ecotourism and also one of the meanings of ecotourism. The fundamental objective of ecotourism is to achieve harmony between human and nature, which is the very core of environmental ethics. However, there are not many researches studying ecotourism in the perspective of environmental ethics and even fewer exploring ethical issues in ecotourism theoretically (Jaakson, 1997; Malloy and Fennell, 1998; Macheth, 2005; Donohoe and Needham, 2006; Holden, 2003; Buckley, 2005). Although these researches point out the importance of environmental ethics in ecotourism, few of them have done practical study or explored the quantitative method.

Value cognition is an important issue in environmental ethics. Tourists are the important components, major participants and receivers of services in ecotourism. This paper took tourists' value cognition as the research object and creatively introduced the value assessment approach in eco-economics so that to work out the suitable experimental model for environmental ethics based quantitative researches. Policy suggestions were made in according to the research results.

In the methodology of ecological economics, the non-market value assessment of ecological products and services with no market transactions or actual market price will depend on hypothetical/created market approaches, where a factitious market context is created to conduct value assessment. The typical one among hypothetical/created market approaches is Contingent Valuation Method (hereinafter referred to as CVM) and CE (Edward-Jones et al., 2000). In CVM investigation, people were asked to price 
products and services. The "contingent" in CVM means the hypothetical market context built in assessment. People were supposed to answer directly the highest price they would be willing to pay for a given product/service or the highest compensation they would be willing to accept for the its absence. In CE, questionnaires were designed to offer a series of option options. A choice set of different levels of certain attributes of products and services was contained in each option. Interviewees could choose the levels of those attributes that they most favored in each option.

As an early age method, CVM is widely used. But the inaccuracy caused by its limitations has invited criticisms from many researchers at home and abroad. Despite its wide application, its validity and reliability are still controversial (Venkatachalam, 2004). Some extreme opinions even stand for abandonment of CVM (Diamond and Hausman, 1994).

As a relatively new method, $\mathrm{CE}$ has some potential advantages over CVM (Edward-Jones et al., 2000). Researchers have studied the same object with two different methods and compared their results. CE turned out to be more effective (Hanley et al., 1998; Mogas et al., 2009). CE is advantageous in behavioral analysis: incentive measures are controlled in the hands of experimenters; orthogonal matrices provide the biggest statistical benefits; the various changes of attributes can be observed; the introduction and exclusion of products and services can be done directly (Louviere and Hensher, 1983).

The choice experiment model was firstly put forward by Louviere and Hensher (1983) when they were studying marketing problems (Louviere and Woodworth, 1983). Later, he and other researchers continued to summarize and improve this method (Louviere et al, 2000; Louviere et al, 2011). At first, this model was mostly used in the field of marketing and transportation (Morrison et al., 1999; Layton and Brown, 2000; García-Llorente et al., 2012; Cerda et al., 2013). Then, it was introduced into environmental researches to conduct non-market value assessment of environmental resources. While wildly used in the field of environmental resources, it was rarely used in tourism researches, all of which aiming at finding out the favored services of benefited groups, mainly tourists. No matter pure preference assessment (Figini and Vici, 2012; Dellaert et al., 1995; Hearne and Santos, 2005; Albaladejo-Pina and Díaz-Delfa, 2009; Hearne and Salinas, 2002) or exploration of willingness of payment (Chaminuka et al., 2012; Can and Alp, 2012), no matter assessment of environmental resources improvement (Hearne and Santos, 2005; Hearne and Salinas, 2002; Can and Alp, 2012) or the offer of tourism services (Dellaert et al., 1995; Albaladejo-Pina and Díaz-Delfa, 2009; Chaminuka et al., 2012), they all contributed to decision-making in tourism development for resource value improvement and a better economic performance. That is to say, the choice experiment model had a good performance in disclosing the value cognition of tourists and other benefited groups in a quantified way and could provide scientific basis and suggestions for operators' $\mathrm{s}$ decision-making and governments' policy-making. 
For the above reasons, choice experiment model was adopted in this study to convert tourists' cognition of ecological value into their virtual willingness of payment for the improvement of different aspects of ecotourism.

\section{Study sites}

Zhejiang province is located in the south of Yangtze River Delta on the southeast coast of China. For its superiority in resource, market, economy and other tourism relevant conditions, its ecotourism is enjoying a vigorous development. In the meantime, Zhejiang province attaches great importance to tourist economy development in counties. Through construction of counties with powerful tourist economy, tourism of their surrounding areas is greatly improved because of a radioactive influence. Tourism development is also pushing forward an industry transformation and upgrading of local economy (Zhao, 2012).

In this context, three ecological counties in north Zhejiang were chosen as study sites. Tonglu, Anji and Lin'an are beautiful in scenery, ecological in environment and experienced in ecotourism practice, so they are qualified to represent the relatively mature ecotourism destinations.

\section{Methods}

\section{Theoretical background of the choice modeling approach}

In Choice experiment model, through making the choice unity model of on the basis of unity maximization theory, interviewees will be offered with choice sets consisting of attributes with different levels in a virtual context and they are supposed to pick out what they most favore. Their choices will be analyzed in an econometrical way to work out the values of different attributes and a relative profit or loss of each option. After that, interviewees' preferences could be found.

Assume that Interviewee $\mathrm{n}$ chose Option $\mathrm{i}$ and its direct unity function $U_{n i}$ is:

$$
U_{n i}=V_{n i}+\varepsilon_{n i}
$$

In the above function, $\mathrm{Vni}$ is the indirect unity function for Interviewee $\mathrm{n}$ choosing Option $\mathrm{i}$ and $\varepsilon_{n i}$ is the unobservable unity for Interviewee $\mathrm{n}$ choosing Option $\mathrm{i}$, namely random error.

According to the premise, interviewees will only choose the option with maximum unity. So the probability of Interviewee $n$ choosing Option i rather than Option $j$ from Choice Set $\mathrm{C}$ can be described as:

$$
P(i / C)=P\left(V_{n i}+\varepsilon_{n i}>V_{n j}+\varepsilon_{n j}\right)
$$


where $i \neq j$ and $j \in C$.

Assumptions about the distribution of $\varepsilon$ will result in different models. In multinomial logit model (hereinafter referred as MNL), unity stochastic items are assumed to be independently and identically distributed (hereinafter referred as IID). So the probability of Interviewee $n$ choosing Option i is:

$$
P\left(n_{i}\right)=\frac{\exp \left(\mu V_{n i}\right)}{\sum_{j \in C} \exp \left(\mu V_{n j}\right)}
$$

where the scalar constant $\mu$ is generally valued 1 .

Thus, the observable unity function of Interviewee $n$ choosing Option $\mathrm{i}$ can be assumed to be a linear function as:

$$
V_{n i}=C+\sum \beta_{k} X_{k}
$$

where $C$ is the alternative specific constant (hereinafter referred as ACS) explaining unobservable attributes' influence on choices. $X_{k}$ is the specific No. $k$ attribute of option $i$ and $\beta \mathrm{k}$ is its coefficient. So:

$$
C S=-\frac{1}{\alpha}\left[\ln \left(\sum \exp V_{i 0}\right)-\ln \left(\sum \exp V_{i 1}\right)\right]
$$

where $C S$ is the benefit of compensating surplus. $V_{i 0}$ and $V_{i 1}$ are marginal unity functions before and after the change of attribute levels. $\alpha$ is the marginal unity of income and usually described as the estimated cost coefficient $\beta_{\text {cost }}$.

The value of an attribute in modeling can be described by the cost that interviewees are willing to pay for its improvement, namely willingness to pay (WTP):

$$
W T P=\frac{-\beta_{\text {attribute }}}{\beta_{\text {cost }}}
$$

where $\beta_{\text {attribute }}$ is the estimated coefficient of each attribute.

\section{Design of the choice experiments}

\section{Attributes and levels}

Out of the perspective and purpose of this study, an experimental survey was conducted with reference to relevant research findings in the three counties. After discussion with some experts, the attributes and their levels used in choice experiment were determined (Table 1). 
Table 1. Attributes and levels used in choice experiment

\begin{tabular}{|c|c|c|c|}
\hline Attribute & Description & \multicolumn{2}{|c|}{ Levels } \\
\hline $\begin{array}{c}\text { Ecological treatment } \\
\text { measures }\end{array}$ & $\begin{array}{l}\text { Strengthen treatment measures } \\
\text { to protect and improve the } \\
\text { ecological environment of the } \\
\text { ecotourism destination }\end{array}$ & $\begin{array}{l}\text { Maintain the } \\
\text { status quo }\end{array}$ & Strengthen \\
\hline $\begin{array}{c}\text { Environmental } \\
\text { education contents }\end{array}$ & $\begin{array}{l}\text { Improve environmental } \\
\text { education measures in the } \\
\text { ecotourism destination }\end{array}$ & $\begin{array}{l}\text { Maintain the } \\
\text { status quo }\end{array}$ & Improve \\
\hline Tourist amount control & $\begin{array}{l}\text { Control the tourist amount of } \\
\text { the ecotourism destination }\end{array}$ & $\begin{array}{l}\text { Maintain the } \\
\text { status quo }\end{array}$ & $\begin{array}{l}\text { Limit the tourist } \\
\text { amount }\end{array}$ \\
\hline Special rural features & $\begin{array}{c}\text { Increase facilities and services } \\
\text { to improve rural features in } \\
\text { ecotourism }\end{array}$ & $\begin{array}{l}\text { Maintain the } \\
\text { status quo }\end{array}$ & $\begin{array}{c}\text { Increase facilities } \\
\text { and services }\end{array}$ \\
\hline Cost increase & $\begin{array}{l}\text { The increase of one ecological } \\
\text { tour cost per capita brought by } \\
\text { the alterations }\end{array}$ & 30 yuan & 60 yuan \\
\hline
\end{tabular}

There are four attributes most meaningful in studying tourists' value cognition in the perspective of environmental ethics and they respectively show the four aspects of tourists' cognition of values where environmental ethics is the core one.

"Ecological treatment measures" reflects tourists' value cognition of their responsibility for environmental protection during ecological touring. No matter those measures are for tourists to get better experiences, or for them to recognize environment's intrinsic value from the perspective of ecological consciousness, they all reflect environmental responsibility. In the study, value cognition of this kind of responsibility is converted into the willingness to pay for improving ecological treatment measures.

"Environmental education contents" reflects tourists' value cognition of ecotourism's function in environmental education. Environmental education function is one of ecotourism's essential characteristics and also part of the important contents in environmental ethics. In this study, value cognition of this kind of education is converted into the willingness to pay for improving environmental education measures.

“Tourist amount control" reflects tourists' value cognition of ecotourism market size. The popularized market of China's ecotourism is one of the special objective phenomena. How to control and deal with this kind of market are mainly the concerns of operators and governments. But from the perspective of tourists, whether they are conscious of tourist amount control in ecological tourist attractions is still to be found. In this study, value cognition of market size is converted into the willingness to pay for improving tourist amount control measures in tourist attractions. 
"Special rural features" reflect tourists' value cognition of the special rural features during ecological touring. As the localization of China's ecotourism, it appears to be more and more rural featured because of the backgrounds of society, history, culture and so on, which can be seen from the development and prosperity of rural tourism as well as the absorption and expression of rural cultures in ecotourism planning, construction and operation. However, from the perspective of tourists, whether they enjoy rural features as an insignificant habit or with value judgments is still to be studied. In this paper, value cognition of rural features is converted into willingness to pay for increasing facilities and services to improve rural features

"Cost" is the increased tour cost covering above improvements, which expresses tourists' willingness to pay in the form of money. This is a virtual situation with complicated factors involved and it can not be exactly described by a simple cost. The specific tour cost here is only a reference point for quantitative judgment. Suppose the precondition is that if tourists are willing to pay more money, it means that they have a higher value judgment for the attribute involved. So by the willingness to pay rather than the exact happening of increased payment, it is convenient to study value cognition. After the statistical survey of one ecological tour cost per capita of urban residents in eastern China, this study set 30 yuan, 60 yuan and 90 yuan as the three levels of tour cost increase so that it will improve the validity of the final choices since it is much closer to the actual situation that interviewees may be in and a too high cost will make interviewees unwilling to make any changes while a too low cost will make them willing to accept all changes.

\section{Choice sets}

When attributes and their levels were decided, orthogonal factors were adopted to design choices on choice cards. There were in total $23 \times 4$ kinds of different choices consisting of choice sets. After elimination of impractical and advantageous alternatives, 24 choice sets were left. To smooth the process of questionnaire investigation, the 24 choice sets were divided into 6 groups, each with 4 choice sets. So there were 6 versions of questionnaires, each with 4 different choice cards. Every Interviewee needed to finish four choice sets to complete one questionnaire. The minimum sample number in a single survey was 6 so that all choice sets enjoyed equal opportunity and the interviewees' choices were valid. During investigations and interviews, these six versions were evenly distributed in all research sites. Table 2 was an example of the choice cards.

In this example, three choices were provided to interviewees. Interviewees must be informed that this survey took the whole industry of ecotourism as the research object, not a specific tourist destination; they should make value judgment with their own standards regardless of the outside influencing factors like operators' strategies and governments' policies; and the increase of tour cost was not reality but a estimated value of a tour cost per capita. 
For interviewees, it could be tested out from choices of different attributes that whether they were willing to pay certain amount of money to improve the current situation of the four aspects of ecotourism, how to achieve the biggest benefits through those improvements and their preferences of a certain improvement under limited budget. In the meantime, what should be noticed was that this study focused on "value of improvement". So the reason for insufficient attention from tourists to a certain aspect could also be that its current situation was good enough and had achieved tourists' inner standards so that attention was attracted to other aspects.

Table 2. Sample choice card from main survey

\begin{tabular}{|c|c|c|c|}
\hline Improvments & Option 1 & Option 2 & Option 3 \\
\hline $\begin{array}{c}\text { Whether to strengthen Ecological } \\
\text { treatment measures }\end{array}$ & Not strengthen & Strengthen & $\begin{array}{l}\text { Maintain the } \\
\text { status quo }\end{array}$ \\
\hline $\begin{array}{c}\text { Whether to improve environmental } \\
\text { education measures }\end{array}$ & Improve & Not improve & $\begin{array}{l}\text { Maintain the } \\
\text { status quo }\end{array}$ \\
\hline $\begin{array}{c}\text { Whether to limit the tourist amount } \\
\text { of the ecotourism destination }\end{array}$ & No limit & $\begin{array}{l}\text { Limit the tourist } \\
\text { amount }\end{array}$ & $\begin{array}{l}\text { Maintain the } \\
\text { status quo }\end{array}$ \\
\hline $\begin{array}{c}\text { Whether to } \begin{array}{l}\text { improve special rural } \\
\text { features }\end{array}\end{array}$ & $\begin{array}{l}\text { Increase facilities } \\
\text { and services }\end{array}$ & $\begin{array}{l}\text { Maintain the status } \\
\text { quo }\end{array}$ & $\begin{array}{l}\text { Maintain the } \\
\text { status quo }\end{array}$ \\
\hline $\begin{array}{l}\text { The increase of one ecological tour } \\
\text { cost per capita }\end{array}$ & $\begin{array}{l}30 \text { yuan } \\
(\quad) \\
\text { Option } 1\end{array}$ & $\begin{array}{l}60 \text { yuan } \\
(\quad) \\
\text { Option } 2\end{array}$ & $\begin{array}{c}0 \text { yuan } \\
(\quad) \\
\text { Status quo }\end{array}$ \\
\hline
\end{tabular}

\section{Design and application of surveys}

After finishing the design of choice cards, the rest of the questionnaire was to be completed. Besides choice cards, single choices and gap fillings were made to conduct a simple survey on interviewees' participation in ecotourism and their personal social and economic conditions. It included that whether it was the first time that they came to this county, how often they participated in ecotourism in recent years, their gender, age, education background, income level and so on. Choices and answers to these questions were set according to the results of the experimental survey. After completion of the questionnaire, Anji Bamboo Garden was taken as the sample site and 30 questionnaires were sent out. According to the feedback, small adjustments were made on expressions and layout of the questionnaire and the final version was thus settled.

From July to October in 2013, 1080 questionnaires, 180 for 6 versions, were sent out in the three target regions averagely, 60 questionnaires for each version in each region. Because of the complexity of the conduction of Choice experiment model method and its specialty, interviewers needed to communicate with interviewees to make sure that they fully understood those hypothetical scenarios and how to make choices in the 
choice cards. Guidance was also necessary in the process of filling the questionnaire. Enough attention was paid to the communication and guidance so that the validity of collected questionnaires was assured and the results could truly reflect interviewees' value cognition.

1060 questionnaires were collected, 1045 valid. Validity rate was 98.5\% (Table 3).

Table 3. Information of the questionnaires

\begin{tabular}{c|c|c|c|c}
\hline & Tonglu & Anji & Lin'an & Total \\
\hline Questionnaires distributed & 360 & 360 & 360 & 1080 \\
Questionnaires collected & 348 & 357 & 355 & 1060 \\
Questionnaires valid & 345 & 354 & 346 & 1045 \\
Validity rate (\%) & 99.1 & 99.2 & 97.5 & 98.6 \\
\hline
\end{tabular}

\section{Results}

In this study, excel was used for initial data process and econometric analysis. Stata11 was then used to conduct MNL modeling analysis of ecotourists' value cognition of ecotourism.

\section{The preferences of ecotourists on all aspects of ecotourism}

According to questionnaire design, interviewees were supposed to make choices among 3 different choice sets. The selected choice set would be valued 1 while those not selected would be 0 . In attribute variables, "increase" and "strengthen" would be valued 1 while "maintain the status quo" would be 0 . On "quantity control of tourists in scenic spots", choosing "support" would be valued 1 while choosing "not necessary" would be 0 . Payment variables would be measured by real numbers. The variable ASC was substitute constant term. Choosing Option 1 and 2 would be valued 1 while choosing Option 3 would be 0 . For variables and their explanations in the model, please see Table 4.

Two MNL models were applied to analyze data separately in this study. The first MNL model only took attribute variables' influence on choices into consideration, while the second one also studied personal variables to explain non-attribute variables' influence on choices.

The indirect utility function of MNL model 1 was:

$$
V_{i}=A S C+\beta_{1} \times E C O+\beta_{2} \times E D U+\beta_{3} \times P O P+\beta_{4} \times A R G+\beta_{5} \times C O S T \text { (Eq.7) }
$$

$(i=1,2,3$; if an interviewee chooses "maintain the status quo", $A S C=0$; if an interviewee chooses Option 1 or $2, A S C=1$ )

MNL model 2 studied social and economic variables and attitude variables' influence on choices through analyzing interviewees' social and economic conditions, their 
participation in ecotourism and the interaction between substitute specific constants. Its indirect utility function was:

$$
\begin{aligned}
& V_{i}=A S C+\beta_{1} \times E C O+\beta_{2} \times E D U+\beta_{3} \times P O P+\beta_{4} \times A R G+\beta_{5} \times C O S T \\
& +\gamma_{1} A S C \times F I R S T+\gamma_{2} A S C \times F R E+\gamma_{3} A S C \times S E X+\gamma_{4} A S C \times A G E \\
& +\gamma_{5} A S C \times D E G R E E+\gamma_{6} A S C \times I N C O M E
\end{aligned}
$$

$(\mathrm{i}=1,2,3$; if an interviewee chooses "maintain the status quo", $A S C=0$; if an interviewee chooses Option 1 or $2, A S C=1$ )

Table 4. The variables and their explanations in the choice experiment model

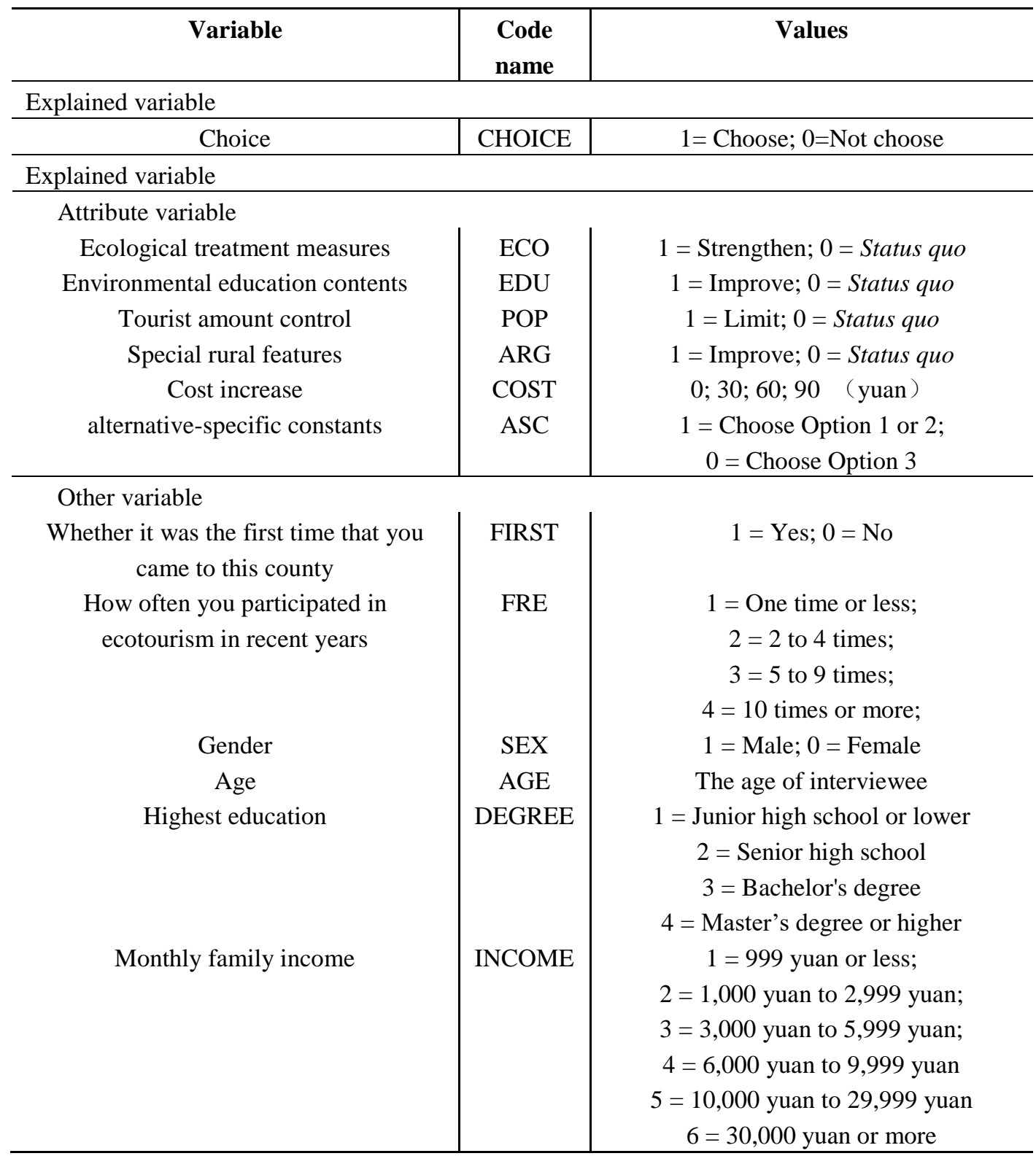


In test results (Table 5), $\mathrm{P}$ was always 0.0000 when hypothesis testing invalid sample mode, which showed that on level 0.01, the model was outstanding. Both the two models were outstanding on level 0.01 and high on overall fitting degree. There was no significant difference between fitting degrees of them. From the symbol and of constants, changes were preferred on the whole by toursists. Ecological environmental management, tourist amount control and special rural features appeared to be welcomed. Tourists tended to be willing to spend a little more money if it was used to improve ecological environmental management, control tourist amount and provide more facilities and services on special rural features' construction. Their experiences on ecotourism had a remarkable influence on their choices. The more experienced, the more willing they are to make changes. Gender, education background and income level also affected interviewees' choices significantly. Women were more willing to make changes and the more education and income they got, the more willing they are to accept the increased cost for improvement measures.

Table 5. Results from multinomial logit model

\begin{tabular}{|c|c|c|c|c|}
\hline \multirow{2}{*}{ Variable } & \multicolumn{2}{|c|}{ Model 1} & \multicolumn{2}{|c|}{ Model 2} \\
\hline & Coefficient & $\mathrm{P}[|\mathrm{Z}|>\mathrm{z}]$ & Coefficient & $\mathrm{P}[|\mathrm{Z}|>\mathrm{z}]$ \\
\hline ECO & $0.4823 * * *$ & 0.000 & $0.4831 * * *$ & 0.000 \\
\hline EDU & 0.0583 & 0.481 & 0.0599 & 0.470 \\
\hline POP & $0.1329 *$ & 0.090 & $0.1345^{*}$ & 0.087 \\
\hline $\mathrm{ARG}$ & $0.1472 *$ & 0.071 & $0.1462 *$ & 0.074 \\
\hline COST & $-0.0053^{*}$ & 0.051 & $-0.0053^{*}$ & 0.051 \\
\hline $\mathrm{ASC}$ & $0.6276 * * *$ & 0.000 & -0.3311 & 0.235 \\
\hline ASC_FIRST & & & 0.1129 & 0.201 \\
\hline ASC_FRE & & & $0.1296^{* *}$ & 0.033 \\
\hline ASC_SEX & & & $-0.2811^{* * *}$ & 0.001 \\
\hline ASC_AGE & & & -0.0003 & 0.940 \\
\hline ASC _DEGREE & & & $0.1832 * * *$ & 0.003 \\
\hline ASC_INCOME & & & $0.0864 * *$ & 0.011 \\
\hline Number of obs & \multicolumn{2}{|c|}{12540} & \multicolumn{2}{|c|}{12540} \\
\hline Log likelihood & \multicolumn{2}{|c|}{-4312.5581} & \multicolumn{2}{|c|}{-4294.603} \\
\hline Prob>chi2 & \multicolumn{2}{|c|}{0.0000} & \multicolumn{2}{|c|}{0.0000} \\
\hline Pseudo-R2 & \multicolumn{2}{|c|}{0.0609} & \multicolumn{2}{|c|}{0.0648} \\
\hline
\end{tabular}

Significant at $* 10 \%, * * 5 \%$ and $* * * 1 \%$.

\section{Ecotourists' virtual payment willingness on ecotourism improvements}

According to Eq.6, attribute coefficients which performed better in model fitting could be used to calculate virtual payment willingness. Results (Table 6) showed that generally ecological environmental management enjoyed the highest virtual payment willingness with tourist amount control and special rural features next to it, while environmental education didn't perform well. 
Table 6. Ecotourists' virtual payment willingness on ecotourism improvements (yuan, each person of each time)

\begin{tabular}{c|c|c|c|c}
\hline Variable & Tonglu & Anji & Lin'an & Total \\
\hline Ecological treatment measures & 209.66 & 49.05 & 179.00 & 91.00 \\
Environmental education contents & $(2.62)$ & $(11.65)$ & $(50.79)$ & $(11.00)$ \\
Tourist amount control & 81.14 & $(21.20)$ & $(-40.64)$ & 25.08 \\
Special rural features & $(38.72)$ & 32.21 & $(-2.36)$ & 27.77 \\
\hline
\end{tabular}

Figures in brackets are for reference only as the coefficients are not highly significant.

\section{Discussion}

\section{Tourists' value cognition of ecotourism}

Tourists prefer to make improvements on the four aspects of ecotourism. It reflects the market potential of China's ecotourism. Consumers are willing to spend more money to have better ecotourism experience. So those improvements can bring more economic benefits. From the angle of environmental ethics, it also reflects tourists' value cognition of responsibility, education and rural features. Since human-oriented, those values have limitations to some degree.

\section{Value cognition of environmental responsibility}

From the results of modeling, it can be seen that tourists have positive value cognition on treatment measures for ecological environment protection and improvements. It reflects that tourists are conscious of their environmental responsibility no matter it was out of their need for better environmental experiences, or their ecological awareness of the intrinsic values of environment. Even participants of popularized tourism have showed high sense of responsibility towards environment. On the other hand, through tourists' willingness to pay more on ecological treatment measures, it is reflected that generally they are worried or unsatisfactory about the present condition of ecological environment during their ecological touring. For tourists, favorable ecological environment is the most important factor in ecological touring and it is also the foundation of ecotourism development. So they are willing to shoulder the responsibility of environmental improvements.

In the meantime, to respond to toursists' sense of responsibility, governments and operators of ecotourism are supposed to work out ecological treatment measures actively, take advanced technologies into ecotourism practice reasonably.

\section{Value cognition of environmental education}

Although environmental education is an important factor both in ecotourism essence and environmental ethics, it is not given enough attention. From the results of modeling, 
the attribute of environmental education did not have a distinct influence on interviewees' choices, which showed that the environmental education function of ecotourism had not been recognized enough by tourists. They were subjectively unconscious of the importance of environmental education and not so willing to pay for it, while ecotourism itself performed the function of environmental education and had an unconscious but important effect on tourists' sense of environmental responsibility and aesthetical appreciation. However, from the symbol of this attribute, it was showed that tourists still preferred to strengthen environmental education. During interviews, some interviewees were found to have expressed their strong need for environmental education, especially for their children. On one hand, there was not enough demand with consciousness for environmental education, so it was more often functioning in the way of invisible influence rather than in visible forms. On the other hand, tourists had a much larger expectation for enjoyment rather than education from environment, so tourists' ecological consciousness was indeed unsatisfactory.

\section{Value cognition of market size}

Results showed that tourists had tended to support controlling the amount of tourists in scenic spots. But this was not obviously reflected in the way of payment willingness. It meant that tourists had realized that too many tourists would affect their own experience of ecotourism but the current situation had not exceeded their psychologically acceptable amount. Meanwhile, during interviews, some of the interviewees had expressed a just attitude which was that tourist amount should not be controlled because everyone has an equal right in enjoying tourism resources.

\section{Value cognition of rural features}

It was accordant to the anticipation of this study that tourists appeared positive value cognition towards rural features. They were obviously more willing to pay for more choices of rural featured facilities and services. It would be a very promising research orientation during China's ecotourism development to take full advantage of tourists' appreciation of rural features and improve the quality of ecotourism accordingly.

\section{The influence of ecotourism experiences on tourists'value cognition}

The number of times of interviewees' ecotours in recent years had an obvious influence on their choices. The number could reflect their interest in ecotourism and thus implied how experienced they were in ecotourism. The more interested and experienced ecotourists were, the more willing they were to make improvements in these four aspects. It also showed that ecotourists with more ecotourism experiences had stronger ecological consciousness. On one hand, tourists with stronger ecological consciousness would take part in ecotourism more actively. One the other hand, the process of ecotourism would improve tourists' ecological consciousness. Whether they were a frequent visitor of one of the three study sites did not have a significant influence 
on their choices, which showed that interviewees' choices had not been influenced by their former travelling experiences in that site.

\section{The influence of tourists' social and economic conditions on their value cognition}

Under this category, only gender, education background and income level had important influence on interviewees' choices. Women were more tended to pay for ecotourism improvements, and the more education and income they got, the more willing they were to undertake the increased cost for improvements. The influence of gender was special because of how it worked and where it originated were complicated. So it would not be discussed in this study. The influence of education background showed that education had improved tourists' ecological consciousness. The influence of income level showed that ecotourism development had been limited by tourists' economic condition. According to our statistical result, most tourists belonged to middle income group. It was believed that as income increasing, ecotourism improvements would have better market environment. Interviewee's age had no obvious influence on choices in modeling.

\section{Policy suggestions}

\section{The importance of ecological treatment measures}

Tourists have expressed strong payment willingness towards increasing ecological treatment measures, which shows that ecological environment was quite valuable for ecotourists. Scientific researches and development and application of advanced technologies are a must for ecological environment protection and improvements. The responsibility for environment not only falls on governments and research institutions, but also is what tourists wanted and willing to shoulder and share.

\section{Compensation to the lack of environmental education}

Tourists have not showed obvious concern to environmental education which reflects an underestimation of the value of environment education. However, environmental education has a significant position both in ecotourism essence and the key conceptions of environmental ethics. The result shows that there is a lack of environmental consciousness in China's ecotourists and this is why there is no big difference between ecotourists and normal tourists. To win a healthy development of ecotourism, China must take this weakness seriously and take measures accordingly. On one hand, education about and for environment should be strengthened in forms such as environment classroom and science popularization, so national ecological consciousness, including ecotourists', can be improved. On the other hand, when planning and designing ecotourism, more efforts need to be put into exploring how to make education in environment function better. Since human guided environmental education is not welcomed by tourists, a more acceptable and natural way as in the form of influencing power needs to be used. 


\section{Market size control}

Tourists have certain concern and payment willingness over measures for tourist amount control in scenic spots. As nature has a capability limit for the environment of ecotourism destinations, tourists also have a psychological capability limit for it. When tourist amount has not passed their bottom line, they tend to choose no limitation on tourist amount, or they might even show the just attitude to object to limitation measures for environmental resources should be fairly enjoyed by everyone. In the meantime, they are also aware of that too many tourists will have a negative effect on environment and their ecological touring experiences. Generally, there is a great difference of tourist amount between holidays and non-holidays, so it is urgently demanded to control it during holidays. Therefore, some control is needed over tourist market size. Direct limitations are unacceptable while it will be better to separate tourists of a certain scenic spot at a certain time in ways such as changing holiday modes and tourists' idea about having holidays.

\section{Flexible use of rural features}

The analysis of tourists' value cognition has showed that there is a special appreciation of rural features in China's ecotourism. Tourists are showed an apparent preference to rural featured facilities and services. This preference is even appeared in non-agriculture ecotourism. So it is obvious that rural features are very favorable among China's ecotourists. When planning and designing ecotourism, adding more rural elements in a harmonious and reasonable way will meet China's ecotourists' needs better.

\section{Conclusion}

The choice experiment model has estimated the value of subjects that cannot be priced through consumers' payment willingness of these attributes. Therefore, it is a method that can make incalculable value into calculable value and also explore interviewees' preference and recognition of a certain attribute through their payment willingness of all attributes. In environmental ethics, value is the core issue. But traditional researches only measure and compare the intangible mental tendency in a descriptive way. The choice experiment model is introduced in this study as an effective way to visualize and quantize this intangible exploration so that to offer a more scientific proof to the research and conclusion of value cognition. Problems are found and summarized from collected data and policy suggestions are put forward on the basis of above results.

There are some weaknesses about the choice experiment model which are also reflected in the study. It is still on the exploring stage of researching the environmental ethical features of tourists with the choice experiment model, so some problems about the way to use the model have arisen, for example, the limitation of a certain interviewee's cognition ability, the limitation of choosing plan scenarios, high cost, 
difficulty in technical analysis, the influence of characteristics of other local scenic spots of the three regions and so on.

Attention needs to be paid on following issues when evaluating tourists' value cognition through the choice experiment model:

- The number of virtual payment willingness of each attribute must be set by the results of the experimental survey and further confirmed and adjusted by the trial survey conducted after. So the number will not be too big or small to make extreme results happen and the modeling will thus be valid.

- Effective communication is needed to ensure that interviewees fully understand the virtual scenarios given in the questionnaire and therefore make the valid judgment.

- Supervision is needed when questionnaires are being done. After being collected, inspection is needed. So there will be as less invalid questionnaires as possible. When interviewees are making invalid choices such as multiple choices and missed choices, interviewers should remind them in time to avoid invalid situations.

- To simplify questionnaire, only questions needed in the model will be on the paper. Other relevant questions will be studied with statistics and on-the-spot investigations. Too many questions will result in mental contradiction of interviewees.

Acknowledgements. We gratefully acknowledge the invaluable contribution of Ms. Jiang Hong who helped us in proofreading this paper.

\section{REFRENCES}

[1] Albaladejo-Pina, I. P., Díaz-Delfa, M. T. (2009): Tourist preferences for rural house stays: Evidence from discrete choice modelling in Spain. - Tourism Management 30(6): 805-811.

[2] Bandara, R. (2009): The practice of ecotourism in Sri Lanka: An assessment of operator compliance towards international ecotourism guidelines. - South Asia Economic Journal 10(2): 471-492.

[3] Blersch, D. M., Kangas, P. C. (2013): A modeling analysis of the sustainability of ecotourism in Belize. - Environment, Development and Sustainability 15(1): 67-80.

[4] Broadbent, E. N., Zambrano, A. M. A., et al. (2012): The effect of land use change and ecotourism on biodiversity: A case study of Manuel Antonio, Costa Rica, from 1985 to 2008. - Landscape Ecology 27(5): 731-744.

[5] Buckley, R. (2005): In search of the narwhal: Ethical dilemmas in ecotourism. - Journal of Ecotourism 4(2): 129-134.

[6] Can, O., Alp, E. (2012): Valuation of environmental improvements in a specially protected marine area: A choice experiment approch in Göcek Bay, Turkey. - Science of the Total Environment 439: 291-298.

[7] Ceballos-Lascurain, H. (1991): Tourism, Ecotourism, and Protected Areas. - In: Kusler, J. A. (ed.) Ecotourism and Resource Conservation. vol.1. Ecourourism and Resource Conservation Project, Berne.

[8] Cerda, C., Ponce, A., Zappi, M. (2013): Using choice experiments to understand public demand for the conservation of nature: A case study in a protected area of Chile. Journal for Nature Conservation 21(3): 143-153. 
[9] Chakrabarty, A. (2011): Ecotourism Development and Security Restructuring: A GI based Plannning for Peaceful Dissuasion of Anarchism in Forest Provinces of India. Procedia Social and Behavioral Sciiences 21(2): 108-115.

[10] Chaminuka, P., Groeneveld, R.A., et al. (2012): Tourist preferences for ecotourism in rural communities adjacent to Kruger Nationgal Park: A choice experiment approach. Tourism Management 33(1): 168-176.

[11] Dellaert, B., Borgers, A., Timmermans, H. (1995): A day in the city - Using conjoint choice experiments to model urban tourists' choice of activity packages. - Tourism Management 16(5): 347-353.

[12] Diamond, P.A., Hausman, J.A. (1994): Contingent valuation debate: is some number better than no number? . - Journal of Economic Perspectives 8(4): 45-64.

[13] Donohoe, H. M., Needham, R. D. (2006): Ecotourism: The evolving contemporary definition. - Journal of Ecotourism 5(5): 192-210.

[14] Edward-Jones, G., Davies, B., Hussain, S. (2000): Ecological Economics: An Introduction. - Blackwell Science Ltd., Oxford.

[15] Fennell, D. A. (2000): Ecotourism: An Introduction. - Routledge, London and New York.

[16] Fennell, D. A. (2001): A content analysis of ecotourism definitions. - CurrentIssues in Tourism 4(5): 403-421.

[17] Figini, P., Vici, L. (2012): Off-season tourists and the cultural offer of a mass-tourism destination: The case of Rimini. - Tourism Managemen 33(4): 825-839.

[18] García-Llorente, M., Martín-Lópe, B., et al. (2012): A choice experiment study for land-use scenarios in semi-arid watershed environments. - Journal of Arid Environments 87(12): 219-230.

[19] Hanley, N., MacMillan, D., et al. (1998): Contingent valuation versus choice experiments: estimating the benefits of environmentally sensitive areas in Scotland. Journal of Agricultural Economics 49(1): 1-15.

[20] Hearne, R. R., Salinas, Z. M. (2002): The use of choice experiments in the analysis of tourist preferences for ecotourism development in Costa Rica. - Journal of Environmental Management 65(2): 153-163.

[21] Hearne, R. R., Santos, C, A. (2005): Tourists' and locals' preferences toward ecotourism development in the Maya Biosphere Reserve, Guatemala. - Environment, Development and Sustainability 7(3): 303-318.

[22] Holden, A. (2003): In need of new envoronmental ethics for tourism?. - Annals of Tourism Research 30(1): 94-108.

[23] Jaakson, R. (1997): Exploring the epistemology of ecotourism. - Journal of Applied Recreation Research 22: 33-47.

[24] Koens, J. F., Dieperink, C., Miranda, M. (2009): Ecotourism as a development strategy: Experiences from Costa Rica. - Environment, Development and Sustainability 11(6): 1225-1237.

[25] Layton. D. F., Brown, G. (2000): Heterogeneous preferences regarding global climate change. - The Review of Economics and Statistics 82(4):616-624.

[26] Li, R. J., Lu, Z., Li, J. F. (2012): Quantitative calculation of eco-tourist's landscape percepetion: Strength, and spatial variationg within ecotourism destination. - Ecological Informatics 10: 73-80.

[27] Louviere, J. J., Hensher, D. A. (1983): Using discrete choice models with experimental design data to forecast consumer demand for a unique cultural event. - Journal of Consumer Research 10(3): 348-361.

[28] Louviere, J. J., Hensher, D. A., Swait, J.D. (2000): Stated choice methods Analysis and applications. - Cambridge University Press, Cambridge. 
[29] Louviere, J. J., Pihlens, D., Carson, R. (2011): Design of discrete choice experiments: A discussion of issues that matter in future applied research. - Journal of Choice Modeling. 2011, 4(1): 1-8.

[30] Louviere, J. J., Woodworth, G. (1983): Design and analysis of simulated consumer choice or allocation experiments: An approach based on aggregate data. - Journal of Marketing Research 20(4): 350-367.

[31] Macheth, J. (2005): Towards an ethics platform for tourism. - Annal of Tourism Research 32(4): 962-984.

[32] Malloy, D. C., Fennell, D. A. (1998): Ecotourism and ethics: Moraldevelopment and organizational cultures. - Journal of Travel Research 36: 47-56.

[33] Mogas, J., Riera, P., Brey, R. (2009): Combining contingent valuation and choice experiments. A forestry application in Spain. - Environ Resource Economics 43(4): 535-551.

[34] Morrison, M., Bennett, J. W., Blarney, R. (1999): Valuing improved wetland quality using choice modeling. - Water Resour. Research. 35(9): 2805-2814.

[35] Muehlenbein, M. P., Martinez, L. A., et al. (2010): Unhealthy travelers present challenges to sustainable primate ecotourism. - Travel Medicine and Infectious Disease 8(3): 169-175.

[36] Reimer, J. K., Walter, P. (2012): How do you know it when you see it? Community-based ecotourism in the Cardamom Mountains of southwestern Cambodia. Tourism Management 34(2): 1-11.

[37] Russell, A. (2007): Anthropology and ecotourism in European wetlands. - Tourist Studies 7(2): 225-244.

[38] Salum, L. A. (2009): Ecotourism and biodiversity conservation in Jozani-Chwaka Bay National Park, Zanzibar. - African Journal of Ecology. 47(Supplement s1): 166-170

[39] Snyman, S. (2012): Ecotourism joint ventures between the private sector and communities: An updated analysis of the Torra Conservancy and Damaraland Camp partnership, Namibia. - Tourism Management Perspectives 4(4): 127-135.

[40] Torres-Sovero, C., Gonzalez, J. A., et al. (2012): Social-ecological factors influencing tourist satisfaction in three ecotourism lodges in the southeastern Peruvian Amazon. Tourism Management 33(3): 545-552.

[41] Venkatachalam, L. (2004): The contingent valuation method: a review. - Environmental Impact Assessment Review 24(1): 89-124.

[42] Winkle, R. (2011): Why do ICDPs fail? The relationship between agriculture, hunting and ecotourism in wildlife consevation. - Resource and Energy Economics 33(1): 55-78.

[43] Wurzinger, S., Johansson, M. (2006): Environmental concern and knowledge of ecotourism among three groups of Swedish tourists. - Journal of Travel Research 45: 217-226.

[44] Zhao, J. Y., Fang, J. H., et al. (2012): Zhejiang's Tourism Development Report (2012). Tourism Bureau of Zhejiang Province, Hangzhou 